Article

\title{
Crop Diversification in Rice-Based Cropping Systems Improves the System Productivity, Profitability and Sustainability
}

\author{
Md Jahangir Alam 1,*(D, Abdullah- Al-Mahmud ${ }^{1}$, Md Aminul Islam ${ }^{2}$, Md Faruque Hossain ${ }^{3}$, Md Akkas Ali ${ }^{3}$, \\ Eldessoky S. Dessoky ${ }^{4}$, Ehab I. El-Hallous ${ }^{4}$, Mohamed M. Hassan ${ }^{4, *(\mathbb{D},}$, Nasrin Begum ${ }^{5}$ and Akbar Hossain ${ }^{6, *(\mathbb{D})}$ \\ 1 On-Farm Research Division (OFRD), Bangladesh Agricultural Research Institute (BARI), \\ Gaibandha 5700, Bangladesh; a.mahmud_bari@outlook.com \\ 2 OFRD, BARI, Bogra 5800, Bangladesh; amin.agron@gmail.com \\ 3 OFRD, BARI, Joydebpur 1701, Bangladesh; faruque1969@yahoo.com (M.F.H.); akkasbari@gmail.com (M.A.A.) \\ 4 Department of Biology, College of Science, Taif University, P.O. Box 11099, Taif 21944, Saudi Arabia; \\ es.dessouky@tu.edu.sa (E.S.D.); e.elhallous@tu.edu.sa (E.I.E.-H.) \\ 5 Bangladesh Betar, Ministry of Information Bangladesh, Rajshahi 6200, Bangladesh; \\ nasrininformation@gmail.com \\ 6 Department of Agronomy, Bangladesh Wheat and Maize Research Institute, Dinajpur 5200, Bangladesh \\ * Correspondence: jahangir.bari@gmail.com (M.J.A.); m.khyate@tu.edu.sa (M.M.H.); \\ akbarhossainwrc@gmail.com (A.H.)
}

Citation: Alam, M.J.; Al-Mahmud, A.-; Islam, M.A.; Hossain, M.F.; Ali, M.A.; Dessoky, E.S.; El-Hallous, E.I.; Hassan, M.M.; Begum, N.; Hossain, A. Crop Diversification in Rice-Based Cropping Systems Improves the System Productivity, Profitability and Sustainability. Sustainability 2021, 13, 6288. https://doi.org/10.3390/ su13116288

Academic Editors: Matthieu Carof, Olivier Godinot and

Mohammad Valipour

Received: 9 May 2021

Accepted: 27 May 2021

Published: 2 June 2021

Publisher's Note: MDPI stays neutral with regard to jurisdictional claims in published maps and institutional affiliations.

Copyright: (ㄷ 2021 by the authors. Licensee MDPI, Basel, Switzerland. This article is an open access article distributed under the terms and conditions of the Creative Commons Attribution (CC BY) license (https:// creativecommons.org/licenses/by/ $4.0 /)$.
Abstract: Cropping systems in the Level Barind Tract (LBT) of Bangladesh are highly diverse, as Transplanted (T.) Aman and Boro (T. Boro) rice are a common practice in the area. Although. T. Aman is generally cultivated in the rainy (monsoon) season, but the $\mathrm{T}$. Boro rice is the intensive irrigation-based winter rice with high establishment costs as a result of exhaustive tillage and high labours for transplanting of seedlings. Furthermore, pumping of a large amount of irrigation during T. Boro cultivation declines the level of groundwater, which is not environmentally friendly nor cost-effective. Therefore, the replacement of the T. Boro rice from the cropping pattern in the LBT area is the major concern of policymakers. In this context, a replicated three to four crop-based cropping systems (CS) field trial was conducted in LBT of Gaibandha, Bangladesh for consecutive three years (2018-2020) to evaluate productivity, profitability and sustainability of the multiple cropbased cropping systems. Among these CS, existing three crops based CS, CS1: T. Aman-Potato-T. Boro (introduction of the local potato in the existing cropping system) were compared with four crops based CS2: T. Aman-Potato-Cucumber-T. Aus (Introduction of high yielding potato, cucumber and T. Aus as an improved cropping system). After two years of observations, significantly higher system productivity (rice equivalent yield; REY) was found in the improved CS2 than that of existing CS1 in both years (two years' average $49 \%$ or $11.1 \mathrm{t} \mathrm{ha}^{-1}$ ). As a result of the introduction of the high yielding potato, cucumber and T. Aus rice instead of the T. Boro rice. The CS2 was also found profitable as compared to the CS1 in terms of higher gross margin (by 74\%), net return (double) and benefit-cost ratio (BCR) (1.69 vs. 1.44) due to higher gross return with slightly higher (by $28 \%$ ) production cost. It is due to farmers received higher prices for potato, cucumber and two rice crops in the improved CS2 than the existing CS1. On the other hand, protein and energy output was lower (by 17\% and 9\%, respectively) in the CS2 than the existing CS1, due to the less content of protein and energy value in the vegetable cucumber. The results of the study revealed that crops diversification in the existing T. Boro based CS with high yielding potato, cucumber, and T. Aus rice, improved the system productivity, profitability and sustainability; which lead to improve the food security of the increasing population and also reduce the adverse effect on the environment.

Keywords: crop; cropping system; intensification; productivity; profitability 


\section{Introduction}

Bangladesh is a small country of 0.148 million $\mathrm{km}^{-2}$ but surprisingly it has to feed 144 million people [1]. Rice is the staple food for most of the people in Bangladesh which occupy about $75 \%$ of the total cropped area [2] and contributes about $95 \%$ of the total food grain [1]. Currently, Bangladesh is now 4th largest rice-producing country in the world after China, India and Indonesia [3]. There are three rice-growing seasons in Bangladesh: Aus (June to August), Aman (August to October) and Boro (February to May) rice. The transplanted Boro (T. Boro) are now the major contributors to total rice production (18.9 Mt) in the country, despite Aman coverage an area of $17 \%$ more than Boro [2]. Currently, about 36.4 million-ton $(\mathrm{Mt})$ of rice is being produced from an area of 11.5 million hectares (Mha) of land with an average of $3.16 \mathrm{tha}^{-1}$ [1]. Although rice production increased more than three folds in the last few decades, the country still could not attain sustainable self-sufficiency in food. Moreover, frequent occurrence of devastating floods, droughts, cyclones, etc., result in disruption to the overall supply of food grains. The average predicted population of Bangladesh will be 182 and 192 million in 2025 and 2030, respectively, and the average rice requirement predicted to be 36.4-37.7 and 40.1-41.0 Mt [4]. Besides, T. Boro rice production is cost-intensive due to more labours and irrigation [5], farmers do not want to sacrifice the Boro rice for their food security. Potato is an important tuber crop and main vegetable in Bangladesh, and considering the area and production, it ranks 2nd position after rice. Currently, about $9.65 \mathrm{Mt}$ of potato were produced from an area of $0.47 \mathrm{Mha}$ with an average yield of $20.6 \mathrm{t} \mathrm{ha}^{-1}$ [1]. Farmers for this reason usually cultivate local potato cultivar (cv. Lalpakri) that are less yielded. On the other hand, cucumber is another important vegetable produced in the specific area of Bangladesh, with small coverage and produced $0.12 \mathrm{Mt}$ from 0.02 Mha of land with an average of $7.75 \mathrm{t} \mathrm{ha}^{-1}$ [3], but are highly profitable due to more market price with higher crop yield and popularly grown among the farmers of this region. Farmers of Level Barind Tract of Bangladesh usually cultivate local and longduration T. Aman varieties (Gutiswarna, duration 150 days), delayed the timely sown of the next crop. The late rice harvest of T. Aman varieties [6] reduces the chance of there being sufficient soil moisture after T. Aman harvest with which too late sown of the succeeding rabi crops. The late harvest of T. Aman rice and increased T. Boro rice cultivation (32\% from 2008 to 2015) under the rice-based cropping system causes the decline of rabi crop yield $[7,8]$. So, there have an opportunity to introduce the short-duration high yielding $\mathrm{T}$. Aman variety (BRRI dhan57) instead of the long duration Gutiswarna (local) rice cultivar, which can help to intensify the existing cropping system. The population of Bangladesh is increasing at $1.37 \%$ p.a. [1], with the decreasing of cultivable land by $1 \%$ p.a. (0.08 Mha) due to rapid urbanization as well as industrialization especially by garments industries [9], and a competitive world market, the challenge of ensuring future food security is daunting. Therefore, there is a need to increase the productivity, profitability and sustainability of rice-based cropping systems by system intensification.

The cropping system of Bangladesh is usually rice-based as well as diversified, includes tuber crops, pulses, oilseed, vegetables, and other winter cereals like maize and wheat. In the level Barind tract of Bangladesh, T. Boro-T. Aman-potato (dry season rice, locally called boro rice, and rainy season rice, called Aman rice) is one of the major cropping systems. Currently, about 0.18 Mha of land (2.11\% of the net cropped area) under this cropping system in Bangladesh [10]. The productivity and sustainability of rice-based systems are threatened because of inefficient use of inputs (seed, fertilizer, scarcity of resources (water and labour), climate change, energy crisis and rising fuel prices, the rising cost of cultivation and emerging socioeconomic changes such as urbanization, migration of labour, preference of nonagricultural work as well as declining soil fertility $[5,11,12]$. Besides, farmers' withdrawal of huge groundwater during the T. Boro rice cultivation, caused the lowering of water tables [13]. Hence the irrigation cost is increasing day by day as well as the need to install more expensive pumps (deep tube-wells, DTW). Moreover, the more uplift of groundwater has led to the accumulation of heavy metals especially arsenic ( $\mathrm{As})$ and lead $(\mathrm{Pb})$ in the groundwater [14-18]. As a result, irrigated (T. Boro) rice 
caused to bring a lot of arsenic into the food chain [19-21]. Thus the T. Aman-Potato-T. Boro cropping systems as currently practised are not sustainable. Therefore, an alternative cropping system is needed that will reduce the production cost, increase crop productivity, reduce adverse effects on the environment as well as sustainable food production. One potential way of achieving this is to switch short duration T. Aman (BRRI dhan57) in place of long duration T. Aman (Gutiswarna) variety, include high yielding potato cultivar, discard the T. Boro rice (cost-intensive) in the existing cropping system and introduce the profitable vegetable crop cucumber and T. Aus; the improved T. Aman-Potato-Cucumber-T. Aus cropping system will increase the total system productivity, profitability and sustainability of the rice-based cropping system as well as help food security (by two rice crops T. Aus and T. Aman) for the ever-growing population of Bangladesh. Given the above, a two-year cropping system experiment was conducted to evaluate (a) the effects of cropping system intensification from T. Aman-Potato-T. Boro to T. Aman-Potato-Cucumber-T. Aus; (b) the introduction of the short duration T. Aman and high yielding potato variety in the improved cropping system and also (c) the system REY performance, protein and energy output in both cropping systems. This research also tried to find out the outcomes of system performance in terms of crop yield, system productivity, profitability and sustainability of the improved cropping system in the Level Barind Tract of Bangladesh.

\section{Materials and Methods}

\subsection{Site Description, Edaphic and Climatic Condition}

The experiment was conducted over two years (2018 to 2020) in the farmer's field of Dhaperhat, Sadullahpur, Gaibandha, Bangladesh $\left(25^{\circ} 36^{\prime} \mathrm{N}, 89^{\circ} 35^{\prime}\right.$ E and $25 \mathrm{~m}$ ASL $)$ under the supervision of On-Farm Research Division (OFRD), Bangladesh Agricultural Research Institute, Gaibandha. The land at the experimental site was flood-free high land, deep grey terrace soil under the agro-ecological zone (AEZ-25) of level Barind tract [22]. The soil was silty clay loam with low water holding capacity. The topsoil $(0-15 \mathrm{~cm})$ was slightly acidic ( $\mathrm{pH}$ 6.2), low organic matter content $(0.93 \%)$ and most of the nutrients are low to medium (Table 1). Before setup, the experiment this site had a history of growing upland crops like rice, potato, sweet gourd, and others. The climate of this region is subtropical monsoon with an average annual rainfall of $907 \mathrm{~mm}$, about $95 \%$ of which usually occurred from May to October (Figure 1a) and the monthly average maximum temperature ranges from 26 to $36{ }^{\circ} \mathrm{C}$, while the monthly average minimum temperature ranged from 12 to $26.4{ }^{\circ} \mathrm{C}$ (Figure 1b).

Table 1. Initial soil properties of the experimental site.

\begin{tabular}{|c|c|c|c|c|c|c|c|c|}
\hline \multirow{2}{*}{ Soil Depth $(0-15 \mathrm{~cm})$} & \multirow{2}{*}{$\mathrm{pH}$} & \multirow{2}{*}{ OM (\%) } & \multirow{2}{*}{ Total N (\%) } & $\mathbf{P}$ & $\mathbf{K}$ & $\mathrm{S}$ & Zn & B \\
\hline & & & & \multicolumn{5}{|c|}{$\mu \mathrm{g} / \mathrm{g}$ Soil } \\
\hline Value & 6.20 & 0.93 & 0.03 & 13.8 & 0.25 & 20.2 & 0.88 & 0.26 \\
\hline Interpretation & Slightly acidic & VL & VL & $\mathrm{L}$ & $\mathrm{M}$ & $\mathrm{M}$ & $\mathrm{L}$ & $\mathrm{L}$ \\
\hline
\end{tabular}

$\mathrm{VL}=$ very low, $\mathrm{L}=$ low, $\mathrm{M}=$ medium.

\subsection{Experimental Design}

The experiment was laid out in a randomized complete block design (RCBD) with seven dispersed replications. The existing two crops based CS were compared with three crops based CS1: T. Aman-Potato-T. Boro (existing cropping system) and four crops based CS2: T. Aman-Potato-Cucumber-T. Aus (improved cropping system). The unit plot size was $600-2600 \mathrm{~m}^{2}$. The experiment commenced with the transplanting of T. Aman crops in July 2018. 


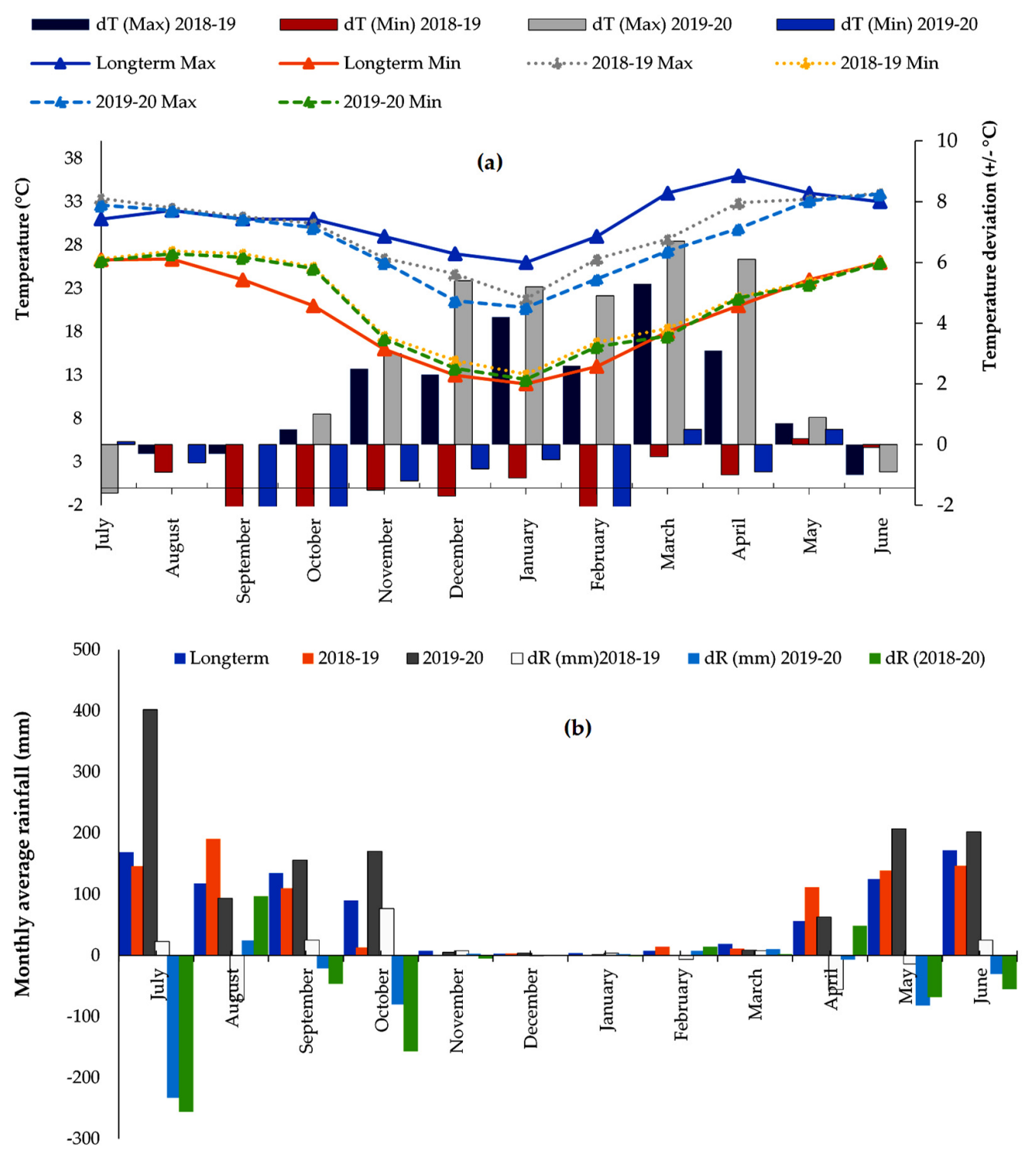

Figure 1. (a): Monthly mean maximum and minimum temperature and (b): monthly mean rainfall (mm) during the two years in comparison to the long term (1985 to 2015).

\subsection{Crop Management}

There are three rice-growing seasons in Bangladesh: Aus (June to August), Aman (August to October) and Boro (February to May) rice. However, potato and cucumber crops were used in the research to replace Boro rice. Details for all crops used in the present research are discussed in the following sub-headings:

\subsubsection{Transplanted Aman Rice (Monsoon Rice)}

Sprouted seeds of BRRI dhan57 (duration 105 days), used in the improved cropping system were broadcast between 28-31 July and Gutiswarna (duration 150 days), used in the existing or farmers cropping system between 5-10 June each year at $35 \mathrm{~kg}$ seed ha ${ }^{-1}$. Seven days before transplanting the field was puddled by ploughing (four passes) using a 2-WT, followed by 2-3 times laddering. Twenty-five-day-old seedlings were uprooted carefully from the seedbed and transplanted on 1-7 July (for Gutiswarna) and 23-26 August (for BRRI dhan57) in both the year, with 2-3 seedlings hill ${ }^{-1}$ maintaining $20 \mathrm{~cm} \times 20 \mathrm{~cm}$ hill spacing. Total fertilizer application was $55 \mathrm{~kg} \mathrm{~N} \mathrm{ha}^{-1}$ as urea, $16 \mathrm{~kg} \mathrm{P} \mathrm{ha}^{-1}$ as triple superphosphate, $35 \mathrm{~kg} \mathrm{~K} \mathrm{ha}^{-1}$ as muriate of potash, $10 \mathrm{~kg} \mathrm{~S}$ ha $^{-1}$ as gypsum. All $\mathrm{P}, \mathrm{K}$, $\mathrm{S}$ were broadcast just before transplanting. Urea was applied into three equal splits at 10 DAT, 30 DAT (4-5 tiller 
stage) and 50 DAT (7 days before panicle initiation). As this is a rainy season, so the crop received only two supplement irrigations during the whole crop growing period. Weeds were well controlled by two hands weeding at 15 and 35 DAT. The Aman rice was infested by stem borer and rice bug, which was well-controlled by applying Imidacloprid (Emitaf ${ }^{\circledR}$, Auto Crop Care Limited, Bangladesh.) at $25 \mathrm{~g}$ a.i. ha ${ }^{-1}$ and carbofuran (Furadan $5 \mathrm{G}^{\circledR}$, Padma Oil Company Limited, Strand Road, Chittagong, Bangladesh) at $500 \mathrm{~g}$ a.i. ha ${ }^{-1}$, Rice blast was controlled by spraying Tebukonajol + Triphoxystrobin (Nativo 75WG ${ }^{\circledR}$, Bayer Crop Science, Bangladesh) at $300 \mathrm{~g} \mathrm{ha}^{-1}$. The crops were harvested on 5- 10 November (Gutiswarna) and 14-20 November (BRRI dhan57) in both crops' year. The rice was cut $25 \mathrm{~cm}$ above the ground and rice straw retained in the succeeding crop.

\subsubsection{Potato}

Land preparation was done by $4-6$ ploughing by a 2-Wheel tractor (2-WT) followed by laddering. Two different varieties were used such as the local (Lalpakri) variety (duration 90 days) in the existing/ farmers cropping system and BARI Alu-25 (duration 90-95 d) in the improved cropping system. Potato seeds were sown on 10-15 November (for Lalpakri) and 20-23 November (for BARI Alu-25) each year in both the cropping system at optimum soil moisture level, at $1500 \mathrm{~kg}$ seed ha ${ }^{-1}$, maintaining $60 \mathrm{~cm} \times 25 \mathrm{~cm}$ spacing and $3-5 \mathrm{~cm}$ sowing depth. Potato tubers were treated by carbendazim $(0.1 \%)$ before plantation into the main field to control fungal (Rhizoctonia) infection. Total fertilizer application was $150 \mathrm{~kg} \mathrm{~N} \mathrm{ha}^{-1}$ as urea, $64 \mathrm{~kg} \mathrm{P} \mathrm{ha}^{-1}$ as triple superphosphate, $125 \mathrm{~kg} \mathrm{~K} \mathrm{ha}^{-1}$ as

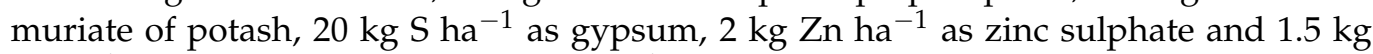
$\mathrm{B} \mathrm{ha} \mathrm{a}^{-1}$ as boric acid along with $10 \mathrm{tha}^{-1}$ well-decomposed cow-dung. Cowdung was applied during the final land preparation. Half of the $\mathrm{N}$ and all the $\mathrm{P}, \mathrm{K}, \mathrm{S}, \mathrm{Zn}$ and $\mathrm{B}$ fertilizers were broadcasted just before plantation, and the rest of $\mathrm{N}$ was top-dressed at 30-35 days after plantation (DAP) as well as the earthing up also done the same time. The crops were irrigated four times in both the years at 8-10 days after planting (DAP), 30-35 DAP, 45-50 DAP and 60-65 DAP maintaining 2/3rd depth of the furrow. Two hand weeding was done at 30-35 DAP and 60-65 DAP by spading in between the ridges and cover the ridges with loose soil, just before 2nd and 3rd irrigation. Carbofuran (Furadan $5 \mathrm{G}^{\circledR}$, Padma Oil Company Limited, Bangladesh) at $500 \mathrm{~g}$ a.i. ha ${ }^{-1}$ was used as basal during final land preparation to control Cutworm infestation and Imidacloprid (Admire 20 SL ${ }^{\circledR}$, Bayer Crop Science Limited Bangladesh Masum Plaza (5th to 7th Floor), Plot \# 13, Road \# 15, Rabindra Sarani, Sector \#3 Uttara, Bangladesh) at $25 \mathrm{~g}$ a.i. ha ${ }^{-1}$ was sprayed in two instalments at 45 and 60 DAP to control Aphid infestation. The crops were also sprayed alternatively with Mancozeb (Dithane-M $45^{\circledR}$, Bayer Crop Science Limited, Dhaka, Bangladesh) at $1.76 \mathrm{~kg}$ a.i. ha ${ }^{-1}$ and Fenamidin at $494 \mathrm{~g}^{\text {a.i. ha }}{ }^{-1}$ (Secure ${ }^{\circledR}$, Bayer Crop Science Limited, Dhaka, Bangladesh) at $15 \mathrm{~d}$ intervals to protect from the Late Blight infection. The crop was harvested on 4-10 February in the existing cropping system and 18-21 February in the improved cropping system at full bulking of the tubers.

\subsubsection{Cucumber}

Cucumber (local variety, duration 85-90 d) was sown in the pit at 20-25 February each of the years at optimum soil moisture level at $6 \mathrm{~kg}$ seed ha ${ }^{-1}$ with a sowing depth of $3-5 \mathrm{~cm}$ and spacing of $1.5 \mathrm{~m} \times 1.5 \mathrm{~m}$. Total fertilizer application was $58 \mathrm{~kg} \mathrm{~N}^{-1}$ as urea, $44 \mathrm{~kg} \mathrm{P} \mathrm{ha}^{-1}$ as triple superphosphate, $100 \mathrm{~kg} \mathrm{~K} \mathrm{ha}^{-1}$ as muriate of potash, $22 \mathrm{~kg} \mathrm{~S} \mathrm{ha}^{-1}$ as gypsum, $3 \mathrm{~kg} \mathrm{Zn} \mathrm{ha}{ }^{-1}$ as zinc sulphate and $1.7 \mathrm{~kg} \mathrm{~B} \mathrm{ha}^{-1}$ as boric acid. Half of the $\mathrm{N}$ and all the $\mathrm{P}, \mathrm{K}, \mathrm{S}, \mathrm{Zn}$ and $\mathrm{B}$ fertilizers were applied in the pit one week before plantation, and the rest of $\mathrm{N}$ was applied at 10-15 DAP and 25-30 DAP as well as weeding at the same time. The cucumber received four post-sowing irrigation at 10-20 DAP, 20-30, 30-40, 60-70 DAP in both the year. There have some fruit fly and aphid infestations in cucumber. Fruit fly controlled by spraying Diafenthiuron (Pegasus $50 \mathrm{SC}^{\circledR}$, Syngenta Bangladesh Limited 755 Satmasjid Road, Dhaka 1205, Bangladesh) at $500 \mathrm{~g}$ a.i. ha ${ }^{-1}$ and Aphid controlled by spraying of Abamectin (Sunmectin $1.8 \mathrm{EC}^{\circledR}$, Auto Crop Care Limited, Bangladesh) at 
$18 \mathrm{~g}$ a.i. $\mathrm{ha}^{-1}$. The crop was harvested from 01 May and continued up to 20 May in each of the years.

\subsubsection{Transplanted Aus Rice}

Sprouted seeds of BRRI dhan 48 (duration $110 \mathrm{~d}$ ) were broadcast at $35 \mathrm{~kg}$ seed ha ${ }^{-1}$ on the seedbed between 28-30 April in each of the years. The main field was puddled by cultivating four passes using a 2-WT, followed by $2-3$ laddering. Twenty-five-day-old seedlings were uprooted carefully from the seedbed and transplanted on 23-26 May each of the years with 2-3 seedlings hill ${ }^{-1}$ and $20 \mathrm{~cm} \times 20 \mathrm{~cm}$ hill spacing. Total fertilizer application was $83 \mathrm{~kg} \mathrm{~N} \mathrm{ha}^{-1}$ as urea, $32 \mathrm{~kg} \mathrm{P} \mathrm{ha}^{-1}$ as triple superphosphate, $75 \mathrm{~kg} \mathrm{~K} \mathrm{ha}^{-1}$ as muriate of potash, $14 \mathrm{~kg} \mathrm{~S} \mathrm{ha}^{-1}$ as gypsum. All the $\mathrm{P}, \mathrm{K}$, and $\mathrm{S}$ fertilizers were broadcast before transplanting. Urea was broadcast in three equal splits at $10 \mathrm{~d}$ after transplanting (DAT), 30 DAT (4-5 tillering stage) and 50 DAT (one week before panicle initiation). Six to seven irrigation was applied in the whole crop growing period. Two hand weeding performed at 25-30 DAT and 45-50 DAT in both the crop growing year, respectively. In both years, the rice was infested by stem borer and rice blast. These infestations were well-controlled by applying Imidacloprid (Emitaf ${ }^{\circledR}$, Auto Crop Care Limited, Bangladesh.) at $25 \mathrm{~g}$ a.i. ha ${ }^{-1}$, carbofuran (Furadan $5 \mathrm{G}^{\circledR}$, Padma Oil Company, Bangladesh) at $500 \mathrm{~g}$ a.i. ha ${ }^{-1}$, tebukona$\mathrm{jol}+$ triphoxystrobin (Nativo $75 \mathrm{WG}^{\circledR}$, Bayer Crop Science, Bangladesh) at $300 \mathrm{~g} \mathrm{ha}^{-1}$. The crops were harvested between 20-25 August over the years. The T. Aus rice was also cut $25 \mathrm{~cm}$ above the ground and retained rice residue similar to T. Aman crop.

\subsubsection{T. Boro}

Sprouted seeds of BRRI dhan 28 (duration $140 \mathrm{~d}$ ) were broadcast at $40 \mathrm{~kg} \mathrm{seed} \mathrm{ha}^{-1}$ on the seedbed between 25-31 December in each year. The main field was puddled by similar practices like T. Aus and T. Aman. Forty-day old seedlings were uprooted carefully from the seedbed and transplanted on 7-15 February in both the year, with 2-3 seedlings hill ${ }^{-1}$ maintaining $20 \mathrm{~cm} \times 20 \mathrm{~cm}$ hill spacing. Total fertilizer application to the main plots was $92 \mathrm{~kg} \mathrm{~N} \mathrm{ha}^{-1}$ as urea, $36 \mathrm{~kg} \mathrm{P} \mathrm{ha}^{-1}$ as triple superphosphate, $80 \mathrm{~kg} \mathrm{~K} \mathrm{ha}^{-1}$ as muriate of potash, $22 \mathrm{~kg} \mathrm{~S} \mathrm{ha}^{-1}$ as gypsum and $3.6 \mathrm{~kg} \mathrm{Zn} \mathrm{ha}^{-1}$ as zinc sulphate and $1.7 \mathrm{~kg} \mathrm{~B} \mathrm{ha}^{-1}$ as boric acid. All P, K, S Zn and B were applied before transplantation of rice seedling into the main field. Urea was broadcast into three equal splits at 10 days after transplanting (DAT), 40 DAT (4-5 tiller stage) and 55 DAT ( 7 days before panicle initiation). The crop received eighteen irrigations during the whole crop growing period. Weeds were well-controlled by 2 hand weedings at 30 DAT and 60 DAT. There were some stem borer infestations, and rice bug at the grain filling stage. Good control of stem borer was achieved by applying fipronil 3G (Regent 3G ${ }^{\circledR}$, BASF Bangladesh Limited, HR Bhaban (4th Floor), 26/1, Kakrail Road, Bir Uttam Samsul Alam Rd, Dhaka 1000, Bangladesh) at $300 \mathrm{~g}$ a.i. ha ${ }^{-1}$ and Flubendiamide (Belt $24 \mathrm{WG}^{\circledR}$, Bayer Crop Science, Bangladesh) at $48 \mathrm{~g}$ a.i. ha ${ }^{-1}$. Rice bug (Leptocorisa oratorius L.) was well controlled by the application of Malathion (Hilthion ${ }^{\circledR}$ The Limit Agro products Limited, House No. 322 (Flat 6A, Rd No 22, Dhaka 1206, Bangladesh) at $570 \mathrm{~g}$ a.i. $\mathrm{ha}^{-1}$ and Imidacloprid (Emifaf ${ }^{\circledR}$ Auto Crop Care Limited, CWS (B) 74, Rd 25, Dhaka 1212, Bangladesh) at $25 \mathrm{~g}$ a.i. $\mathrm{ha}^{-1}$. The crop was harvested on 25-31 May in both years. Rice straw management was the same as other rice crops.

\subsection{Observations}

\subsubsection{Crop Yield}

Grain yield was determined by harvesting from an area of $9 \mathrm{~m}^{2}(3 \mathrm{~m} \times 3 \mathrm{~m})$ area for rice and $4 \mathrm{~m}^{2}(2 \mathrm{~m} \times 2 \mathrm{~m})$ for potato and 5 pits for cucumber in each plot. The rice was manually threshed, and fresh grain and straw weights were determined. The moisture content of rice grain was determined from an average of 3 subsamples using a grain moisture meter (Model: GMK-303RS). Grain yield $\left(\mathrm{t} \mathrm{ha}{ }^{-1}\right.$ ) was measured at $12 \%$ moisture content (rice). 


\subsubsection{System Rice Equivalent Yield}

Rice equivalent yield (REY) of potato and cucumber was calculated from the grain/ tuber/fruit yield and price of each crop using the formula:

$$
\operatorname{REY}\left(\text { of } \operatorname{crop}_{x}\right)=Y_{x}\left(P_{x} / P_{r}\right)
$$

where, $Y_{x}$ is the yield of crop ' $x$ ' ( $\left.\mathrm{t} \mathrm{ha}{ }^{-1}\right), P_{x}$ is the price of crop ' $x$ ' $\left(\mathrm{US} \$ \mathrm{t}^{-1}\right)$ and $P_{r}$ is the price of rice [23]. The price of rice, potato and cucumber used were US\$240, 180 and $144 \mathrm{t}^{-1}$, respectively. These values were calculated from the farmgate price in Bangladeshi taka (BDT), which were converted in US\$ using 1 US\$ $=84.84$ BDT (the exchange rate in March 2020). System REY was determined as the sum of the REY of each crop in both the cropping system.

\subsubsection{System Protein Output}

System protein output was determined from the sum of the protein output in the grain of each crop in the following cropping system using the following formula:

$$
\text { Protein output }\left(\mathrm{kg} \mathrm{ha}^{-1}\right)=\text { Protein } \% \times \text { dry grain yield }\left(\mathrm{tha}^{-1}\right) \times 1000 / 100
$$

The protein content used for rice, potato and cucumber were $8.8,1.9$, and $0.7 \%$ respectively $[24,25]$.

\subsubsection{System Energy Output}

Total system energy output was determined by the sum of energy (the main product of rice, potato and cucumber) and the by-product of rice crop. The energy content used for rice grain, rice straw, potato tuber and cucumber fruit were $14.7,15.6,4.06$ and $0.8 \mathrm{MJ} \mathrm{kg}^{-1}$, respectively [26,27].

\subsection{Sustainable Yield Index (SYI)}

The sustainable yield index (SYI) of the cropping system was calculated by using the following formula:

$$
\mathrm{SYI}=(\mathrm{Ymean}-\mathrm{SD}) / \mathrm{Ymax}
$$

where, Ymean is the mean yield, SD is the standard deviation and Ymax is the maximum yield.

\subsection{System Economic Performance}

The amount of total cost was calculated as the sum of total variable and fixed costs. The price of all inputs and outputs were determined in BDT based on the local market price, which was converted to US\$ using an exchange rate of 1 US\$ $=84.84$ BDT. The variable costs used in the analysis were land preparation, seed, uprooting and transplanting of the rice seedlings, transplantation, fertilizer, insecticide, fungicide, harvesting, threshing, etc. (Tables 2 and 3), and the information provided by the local farmers of that area. The land preparation and irrigation were based on the charges of the local service providers. Fixed costs (land rental value interest on operating cost) are those costs that do not change with the change in the volume and type of production. 
Table 2. Cost of potato and cucumber production used in the economic analysis.

\begin{tabular}{|c|c|c|c|c|c|c|}
\hline \multirow[b]{2}{*}{ Parameters } & \multicolumn{3}{|c|}{ Potato } & \multicolumn{3}{|c|}{ Cucumber } \\
\hline & $\begin{array}{c}\text { Quantity } \\
\left(\text { ha }^{-1}\right)\end{array}$ & $\begin{array}{l}\text { Unit Price } \\
\text { (US\$) }\end{array}$ & Total (US\$) & $\begin{array}{c}\text { Quantity } \\
\left(\text { ha }^{-1}\right)\end{array}$ & $\begin{array}{l}\text { Unit Price } \\
\text { (US\$) }\end{array}$ & Total (US\$) \\
\hline \multicolumn{7}{|l|}{ Variable Cost } \\
\hline Seed $(\mathrm{Kg})$ & 2000 & 0.6 & 1200 & 6 & 24 & 144 \\
\hline Land preparation & 1 & 102 & 102 & 1 & 102 & 102 \\
\hline \multicolumn{7}{|l|}{ Human labour (Man day ${ }^{-1}$ ) } \\
\hline Pit preparation & - & - & - & 12 & 3.6 & 43 \\
\hline Seeding & - & - & - & 10 & 3.6 & 36 \\
\hline Fertiliser & 2 & 4.8 & 10 & 2 & 3.6 & 7 \\
\hline Irrigation & 15 & 4.8 & 72 & 7 & 3.6 & 25 \\
\hline Weeding/Earthing up & 16 & 4.8 & 77 & 7 & 3.6 & 25 \\
\hline Fungicide/Insecticide & 12 & 4.8 & 58 & 7 & 3.6 & 25 \\
\hline Macha preparation & - & - & - & 30 & 4.8 & 144 \\
\hline Harvesting and cleaning & 45 & 4.8 & 216 & 28 & 4.2 & 118 \\
\hline Total labour & 90 & - & 432 & 103 & - & 424 \\
\hline \multicolumn{7}{|l|}{ Fertiliser } \\
\hline Cowdung (t) & 10 & 12 & 120 & - & - & - \\
\hline Urea $(\mathrm{kg})$ & 300 & 0.19 & 58 & 125 & 0.192 & 24 \\
\hline TSP (kg) & 220 & 0.3 & 66 & 220 & 0.3 & 66 \\
\hline MoP (kg) & 250 & 0.19 & 48 & 200 & 0.192 & 38 \\
\hline Gypsum (kg) & 120 & 0.12 & 14 & 120 & 0.12 & 14 \\
\hline Zinc $(\mathrm{kg})$ & 10 & 4.8 & 48 & 10 & 4.8 & 48 \\
\hline Boron $(\mathrm{kg})$ & 10 & 3.6 & 36 & 10 & 3.6 & 36 \\
\hline Irrigation & 2 & 36 & 72 & 4 & 36 & 144 \\
\hline Fungicide (kg) & 10 & 4.8 & 48 & - & - & - \\
\hline Insecticide (L) & 5 & 14.4 & 72 & 5 & 14.4 & 72 \\
\hline String $(\mathrm{Kg})$ & - & - & - & 70 & 3 & 210 \\
\hline Bamboo (no.) & - & - & - & 70 & 1.8 & 126 \\
\hline Total variable cost & - & - & 2316 & - & - & 1448 \\
\hline \multicolumn{7}{|l|}{ Fixed Cost } \\
\hline Interest on OC (\%) & 0.09 & - & 12 & 0.09 & - & 12 \\
\hline Land rental value & 1 & 540 & 135 & 1 & 540 & 135 \\
\hline Total fixed cost & - & - & 147 & - & - & 147 \\
\hline Total cost & - & - & 2463 & - & - & 1596 \\
\hline
\end{tabular}

Table 3. Costs of rice production used in the economic analysis.

\begin{tabular}{|c|c|c|c|c|c|c|c|c|c|}
\hline \multirow[b]{2}{*}{ Parameters } & \multicolumn{3}{|c|}{ T. Aus } & \multicolumn{3}{|c|}{ T. Aman } & \multicolumn{3}{|c|}{ T. Boro } \\
\hline & $\begin{array}{l}\text { Quantity } \\
\text { ha }^{-1}\end{array}$ & $\begin{array}{l}\text { Unit Price } \\
\text { (US\$) }\end{array}$ & $\begin{array}{l}\text { Total } \\
\text { (US\$) }\end{array}$ & $\begin{array}{l}\text { Quantity } \\
\text { ha }^{-1}\end{array}$ & $\begin{array}{l}\text { Unit Price } \\
\text { (US\$) }\end{array}$ & $\begin{array}{l}\text { Total } \\
\text { (US\$) }\end{array}$ & $\begin{array}{l}\text { Quantity } \\
\text { ha }^{-1}\end{array}$ & $\begin{array}{l}\text { Unit Price } \\
\text { (US\$) }\end{array}$ & $\begin{array}{l}\text { Total } \\
\text { (US\$) }\end{array}$ \\
\hline \multicolumn{10}{|c|}{ Variable Costs } \\
\hline Seed $(\mathrm{Kg})$ & 35 & 0.6 & 21 & 35 & 0.48 & 17 & 40 & 0.6 & 24 \\
\hline Land preparation & 1 & 102 & 102 & 1 & 102 & 102 & 1 & 102 & 102 \\
\hline \multicolumn{10}{|c|}{ Human Labour (Man Day ${ }^{-1}$ ) } \\
\hline Seedling uprooting & 7 & 4.2 & 29 & 7 & 3.6 & 25 & 10 & 4.8 & 48 \\
\hline Transplanting & 22 & 4.2 & 92 & 20 & 4.8 & 96 & 21 & 4.8 & 101 \\
\hline Fertiliser & 2 & 4.2 & 8 & 2 & 3.6 & 7 & 3 & 4.8 & 14 \\
\hline Irrigation & 7 & 4.2 & 29 & 4 & 3.6 & 14 & 8 & 4.8 & 38 \\
\hline Weeding & 7 & 4.2 & 29 & 7 & 4.8 & 34 & 10 & 4.8 & 48 \\
\hline Fungicide/Insecticide spray & 7 & 4.2 & 29 & 2 & 4.8 & 10 & 4 & 4.8 & 19 \\
\hline Harvesting and cleaning & 28 & 4.8 & 134 & 20 & 4.8 & 96 & 27 & 4.8 & 130 \\
\hline Total labour & 80 & & 353 & 62 & & 282 & 81 & & 398 \\
\hline \multicolumn{10}{|c|}{ Fertiliser } \\
\hline \multicolumn{10}{|l|}{ Cowdung (t) } \\
\hline Urea $(\mathrm{kg})$ & 180 & 0.192 & 35 & 120 & 0.192 & 23 & 200 & 0.192 & 38 \\
\hline TSP $(\mathrm{kg})$ & 160 & 0.3 & 48 & 80 & 0.3 & 24 & 180 & 0.3 & 54 \\
\hline $\mathrm{MoP}(\mathrm{kg})$ & 150 & 0.192 & 29 & 70 & 0.192 & 13 & 160 & 0.192 & 31 \\
\hline Gypsum (kg) & 80 & 0.12 & 10 & 60 & 0.12 & 7 & 120 & 0.12 & 14 \\
\hline Zinc (kg) & & & & & & & 10 & 4.8 & 48 \\
\hline Boron (kg) & & & & & & & 10 & 3.6 & 36 \\
\hline Irrigation & 7 & 9.6 & 67 & 2 & 9.6 & 19 & 18 & 7.8 & 140 \\
\hline Fungicide (kg) & & & & & & & & & \\
\hline Insecticide (L) & 3 & 14.4 & 43 & 2 & 14.4 & 29 & 2 & 14.4 & 29 \\
\hline Total variable cost & & & 707 & & & 516 & & & 915 \\
\hline Fixed Cost & & & & & & 0 & & & \\
\hline Interest on OC (\%) & 0.09 & & 12 & 0.09 & & 15 & 0.09 & & 18 \\
\hline Land rental value & 1 & 540 & 135 & 1 & 540 & 169 & 1 & 540 & 203 \\
\hline Total fixed cost & & & 147 & & & 184 & & & 221 \\
\hline Total Cost & & & 854 & & & 700 & & & 1136 \\
\hline
\end{tabular}


Land rental cost was the rental value for one year considering the local rental price. Rental values were assigned to each crop based on the duration of the crop; for T. AmanPotato-T. Boro cropping system durations of 3, 4.5 and 4.5 months, respectively, whereas in T. Aman-potato-cucumber-T. Aus cropping system durations of 3 months of each crop. Interest on operating capital (IOC) was calculated using the following equation:

$$
\mathrm{IOC}=\mathrm{TVC} \times \mathrm{i} \times \mathrm{t} /(100 \times 12)
$$

where, TVC $=$ total variable cost, $\mathrm{i}=$ annual interest rate $(9 \%$, current bank interest rate in Bangladesh), $\mathrm{t}=$ length of the crop production period in months (as above).

The gross return for each crop was calculated from the amount of harvested product $t$ $\mathrm{ha}^{-1}$ (grain and straw) and their farmgate prices. The prices of the rice grain, rice straw,

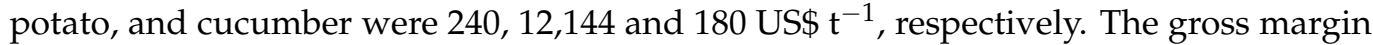
for each crop was determined as the difference between the gross (total) return and total variable cost. Net return was calculated as the difference between gross return and total cost. The benefit-cost ratio (BCR) was calculated from the gross return divided by the total cost. Annual cropping system economic performance was calculated from the sum of the returns and the sum of the costs for each crop in each one-year cycle.

\subsection{Weather Data}

Daily maximum and minimum temperature and rainfall data during the experiment period (2018 to 2020) were collected from the weather station of the Department of Agricultural Extension, Gaibandha. Long term weather data (1985 to 2015) also acquired from the website (https: / www.meteoblue.com/en/weather/historyclimate/climatemodelled/ gaibandha_bangladesh_7921384 (accessed on 9 May 2021).

\subsection{Statistical Analysis}

Data were analysed by t-test using Microsoft excel program and the means were separated using $p$-value at the $5 \%$ level of significance $(p<0.05)$.

\section{Results and Discussion}

\subsection{Weather Variables (Air Temperature and Rainfall)}

\subsubsection{Transplanted Aman Rice}

In the 2018-19 crop season, the maximum and the minimum air temperature were ranged from 21.8 to $34.0^{\circ} \mathrm{C}$ and 13.1 to $27.3^{\circ} \mathrm{C}$. Again, in the $2019-20$ crop season, the maximum and the minimum air temperature were ranged from 20.8 to $33.9^{\circ} \mathrm{C}$ and 12.5 to $27.0^{\circ} \mathrm{C}$. Compared to long-term air temperature data, the average maximum air temperature increased by $1.4{ }^{\circ} \mathrm{C}$ in the $2018-19$ crop season and $2.6^{\circ} \mathrm{C}$ in the $2019-20$ crop season, respectively. Again, the average minimum air temperature decreased by $1.4{ }^{\circ} \mathrm{C}$ in the 2018-19 crop season and $1{ }^{\circ} \mathrm{C}$ in the 2019-20 crop season, respectively. Changes in the rainfall pattern were also observed, in the 2018-19 crop season $20.5 \mathrm{~mm}$ less rainfall was recorded and $406.1 \mathrm{~mm}$ more rainfall was recorded in the 2019-20 crop season compare to the long-term average rainfall data.

The monthly maximum temperature was higher $\left(1.6\right.$ to $\left.2.4^{\circ} \mathrm{C}\right)$ during transplanting of T. Aman (Gutiswarna, used in the existing cropping system) transplantation (July) compared to the long-term average but in the case of BRRI dhan57 (used in the improved cropping system), it was similar. Later on, the temperature was similar to the long term in both the crop growing period with some exception at the maturity stage (end of October) with a deviation of 2.5 to $3.0^{\circ} \mathrm{C}$ (Figure 1a). Conversely, the monthly mean minimum temperature was much higher (up to $4.5^{\circ} \mathrm{C}$ ) compared to the long-term data during the total crop period (July to the first week of November) (Figure 1a). The crop received $460 \mathrm{~mm}$ rainfall in 2018-19, comparatively lower than the long term (512 mm), but occurred reverse in 2019-20 (822 mm), which was much higher than the long-term average. Between the two years, the second year received more rainfall (>362 $\mathrm{mm}$ ) than that of the first crop year (Figure 1b). 


\subsubsection{Potato}

During the crop growth, the maximum monthly average temperature was ranged from 21.8 to $26.5^{\circ} \mathrm{C}$ in the 2018-19 crop season and in the 2019-20 crop season it was from 20.8 to $26.0^{\circ} \mathrm{C}$. Meanwhile, the minimum monthly average temperature was ranged from 13.1 to $17.5^{\circ} \mathrm{C}$ in the $2018-19$ crop season and 12.5 to $17.2^{\circ} \mathrm{C}$. The monthly mean maximum temperature during each potato crop (November to February) was usually lower compared to the long-term average with a deviation of 2.5 to $5.4{ }^{\circ} \mathrm{C}$ across the two years. On the contrary, the monthly mean minimum temperature was slightly higher $\left(0.5\right.$ to $\left.2.8^{\circ} \mathrm{C}\right)$ than the long-term average during the whole potato growing period. The second crop growing year was cooler than that of the first crop growing year (Figure 1a). Rainfall was low during the first and second potato crops, with totals of 18.1 and $10.5 \mathrm{~mm}$, respectively that was slightly lower than the long-term average with a value of $23 \mathrm{~mm}$ (Figure 1b).

\subsubsection{Cucumber}

The monthly mean maximum temperature during every crop growing period of cucumber (March to May) was comparatively lower than the long-term average with a lower of 0.7 to $5.3^{\circ} \mathrm{C}$ in the first year and 0.9 to $6.7^{\circ} \mathrm{C}$ in the second crop growing year. Interestingly, the monthly mean minimum temperature of the whole cucumber growing period was similar to the long-term average (Figure 1a). Rainfall during the cucumber crop growing period of each year was 262 and $279 \mathrm{~mm}$, comparatively higher than the long-term average $(200 \mathrm{~mm})$, especially near about double during the vegetative stage (in April) in the first year but reverse at the harvesting stage (in May) (Figure 1b).

\subsubsection{Transplanted Aus Rice}

The monthly mean maximum and minimum temperature were slightly higher in both the crop growing period of T. Aus (Last week of May to Last week of August) compared to the long-term average (Figure 1a). Likewise, the crop received more rainfall in both the crop year (484 $\mathrm{mm}$ in 2018-19 and $698 \mathrm{~mm}$ in 2019-20), which was more than that of the long term $(459 \mathrm{~mm})$. Among the two-crop season, in the second year, the crop received more than double rainfall in July $(>256 \mathrm{~mm}$ ) during the vegetative period (Figure $1 \mathrm{~b}$ ).

\subsubsection{Transplanted Boro Rice}

The monthly mean maximum temperature was lower in both the crop growing period of T. Boro (February to May) compared to the long-term average with a value of 2.6 to $6.7^{\circ} \mathrm{C}$ across the year and the monthly mean minimum temperature were slightly higher in both the crop year than the long-term average with a deviation of 0.4 to $2.8^{\circ} \mathrm{C}$, but the second year was comparatively cooler than the first year (Figure 1a). Rainfall of the whole crop period was similar (276 $\mathrm{mm}$ in 2018-19 and $278 \mathrm{~mm}$ in 2019-20), higher than the long-term average with a value of $208 \mathrm{~mm}$ (Figure $1 \mathrm{~b}$ ).

\subsection{Crop Duration}

The in-field duration of T. Aman (Gutiswarna) from transplanting to harvest was 126 to 129 days (d) over the two years whereas, it was about 80 to $84 \mathrm{~d}$ in BRRI dhan57, about one and half of month less than the local T. Aman crop variety (Table 4). The duration of potato was about 85 to $87 \mathrm{~d}$ in the local (Lalpakri) variety and 88 to $90 \mathrm{~d}$ for BARI Alu-25, like the local potato variety. The duration of T. Boro was 104 to $108 \mathrm{~d}$ with an average of $106 \mathrm{~d}$ over the two years. The duration of Cucumber was 84 to $86 \mathrm{~d}$ in both the year, with an average of $85 \mathrm{~d}$ and the T. Aus duration was $88 \mathrm{~d}$ in 2018-19 and $90 \mathrm{~d}$ in 2019-20 with an average of $89 \mathrm{~d}$. The in-field duration of all crops was slightly more in the second year compared to the first crop growing year due to the cooler weather throughout the year (Figure 1a). Thus, the total in-field duration of the T. Aman- Potato-T. Boro- (existing) cropping system ( 315 to $324 \mathrm{~d}$ ) was less (about $25 \mathrm{~d}$ ) than that of the T. Aman-Potato-Cucumber-T. Aus- (improved) cropping system ( 340 to $350 \mathrm{~d}$ ), mainly due to the replacement of the local T. Aman (duration 128 days) by BRRI dhan57 (duration $82 \mathrm{~d}$ ) 
crop variety as well as discard long duration of T. Boro crop. It revealed that about $25 \mathrm{~d}$ were more used in the improved cropping system as well as to minimize the turn-around time, resulted in significantly higher system productivity.

Table 4. Field duration (d) of Potato, Cucumber, T. Aus, T. Aman and T. Boro crops and of the total (annual) cropping system.

\begin{tabular}{|c|c|c|c|c|c|c|c|c|c|}
\hline \multirow[b]{2}{*}{ Crop Years } & \multicolumn{3}{|c|}{ Existing Cropping System (CS1) } & \multicolumn{4}{|c|}{ Improved Cropping System (CS2) } & \multicolumn{2}{|c|}{ Total System ${ }^{a}$} \\
\hline & $\begin{array}{c}\text { T. Aman } \\
\text { (Gutiswarna) }\end{array}$ & $\begin{array}{c}\text { Potato } \\
\text { (Lalpakri) } \\
\text { (Local) }\end{array}$ & $\begin{array}{c}\text { T. Boro } \\
\text { (BRRI } \\
\text { dhan28) }\end{array}$ & $\begin{array}{c}\text { T. Aman } \\
\text { (BRRI } \\
\text { dhan57) }\end{array}$ & $\begin{array}{c}\text { Potato } \\
\text { (BARI } \\
\text { Alu-25) }\end{array}$ & $\begin{array}{l}\text { Cucumber } \\
\text { (Local) }\end{array}$ & $\begin{array}{c}\text { T. Aus } \\
\text { (BRRI } \\
\text { dhan48) }\end{array}$ & CS1 & CS2 \\
\hline 2018-19 & $126 \pm 2$ & $85 \pm 2$ & $104 \pm 3$ & $80 \pm 2$ & $88 \pm 2$ & $84 \pm 2$ & $88 \pm 2$ & $315 \pm 2$ & $340 \pm 2$ \\
\hline 2019-20 & $129 \pm 2$ & $87 \pm 2$ & $108 \pm 3$ & $84 \pm 2$ & $90 \pm 2$ & $86 \pm 2$ & $90 \pm 2$ & $324 \pm 2$ & $350 \pm 2$ \\
\hline Mean & $128 \pm 2$ & $86 \pm 2$ & $106 \pm 3$ & $82 \pm 2$ & $89 \pm 2$ & $85 \pm 2$ & $89 \pm 2$ & $320 \pm 2$ & $345 \pm 2$ \\
\hline
\end{tabular}

${ }^{\text {a }}$ CS1 = T. Aman-Potato-T. Boro (Existing cropping system), CS2 = T. Aman-Potato-cucumber-T. Aus (Improved cropping system).

\subsection{Crop and System Rice Equivalent Yield}

Grain yield of the T. Aman crops ranged from 3.90 to $4.90 \mathrm{tha}^{-1}$ across treatments and years. The grain yield of T. Aman crop was significantly higher in the existing cropping system than the improved cropping system mainly due to the use of the high yielded Gutiswarna (local long duration Aman) variety. In both the year T. Aman yielded 23\% higher rice grain compared to the T. Aman in improved cropping system (Table 5). Conversely, the tuber yield of potatoes ranged from 19 to $24.5 \mathrm{t} \mathrm{ha}^{-1}$ over the treatments and years. The tuber yield was significantly higher $(26 \%)$ in the improved cropping system due to the introduction of high-yielding potato (BARI Alu-25) crop variety instead of the local potato (Lalpakri) variety. The grain yield of T. Boro was 5.50 and $5.30 \mathrm{t} \mathrm{ha}^{-1}$ in the first and second crop years. The fruit yield of cucumber ranged from 13.7 to $14.1 \mathrm{t} \mathrm{ha}^{-1}$ over the two years. The grain yield of T. Aus was 4.20 and $4.00 \mathrm{t} \mathrm{ha}^{-1}$ in 2018-19 and 2019-20, respectively. In all the rice crop grain yield was slightly lower in the second year due to some cool temperature during the crop growing period (Figure 1a).

Table 5. Grain yield ( $\mathrm{t} \mathrm{ha}^{-1}$ ) of individual crops and annual cropping system rice equivalent yield (REY, $\mathrm{t} \mathrm{ha}^{-1}$ ) during 2018-19 to 2019-20 and sustainable yield index (SYI) averaged over the two years.

\begin{tabular}{|c|c|c|c|c|}
\hline \multirow{2}{*}{ Crops/Systems } & \multicolumn{4}{|c|}{ Cropping Systems } \\
\hline & CS1 & CS2 & $t$-Value & Level of Significance \\
\hline \multicolumn{5}{|c|}{ 2018-19 } \\
\hline T. Aman & 4.90 & 4.00 & 4.19 & $* *$ \\
\hline Potato & 19.00 & 24.00 & 5.17 & $* *$ \\
\hline T. Boro & 5.50 & - & - & \\
\hline Cucumber & - & 13.7 & - & \\
\hline T. Aus & - & 4.20 & - & \\
\hline System REY & 22.52 & 33.47 & 13.4 & $* *$ \\
\hline \multicolumn{5}{|c|}{ 2019-20 } \\
\hline T. Aman & 4.80 & 3.90 & 3.69 & $* *$ \\
\hline Potato & 19.50 & 24.50 & 6.69 & $* *$ \\
\hline T. Boro & - & - & - & \\
\hline Cucumber & - & 14.1 & - & \\
\hline T. Aus & - & 4.00 & - & \\
\hline System REY & 22.48 & 33.74 & 15.9 & ** \\
\hline Mean system REY & 22.50 & 33.60 & 21.9 & $* *$ \\
\hline Mean system SYI & 0.90 & 0.91 & 0.41 & NS \\
\hline
\end{tabular}

CS1 = T. Aman-Potato-T. Boro (Existing cropping system), CS2 = T. Aman-Potato-Cucumber-T. Aus (Improved cropping system); ${ }^{* *}$, significant at $1 \%$ level of probably. 
System REY ranged from 22.48 to $33.74 \mathrm{t} \mathrm{ha}^{-1}$ over treatments and years. There was a consistent trend of higher REY in the improved (four crop-based) cropping system (33.47 tha $\mathrm{th}^{-1}$ in 2018-19 and $33.74 \mathrm{tha}^{-1}$ in 2019-20 with an average of $33.60 \mathrm{t} \mathrm{ha}^{-1}$ ) than of farmers' existing (three crop-based) cropping system (22.52 t ha ${ }^{-1}$ in 2018-19 and $22.48 \mathrm{tha}^{-1}$ in 2019-20 with an average of $22.50 \mathrm{tha}^{-1}$ ). The REY was $49 \%$ higher in the improved cropping system compared to the existing cropping system due to the higher yield of potato and cucumber as well as the higher price received by the farmers. Reports are available on the increase of REY due to crop intensification as well as diversification. Cropping intensification from single to double increase the system REY by two to four times higher in rice-based cropping system [28-30], even varied 9-34\% from rice-rice to rice-non rice crop based cropping systems [31] in India. Cropping system intensification from double (rice-rice or rice-wheat) to triple cropping system (Wheat-Mungbean-T. Aman) increased the system REY by $10-75 \%$ in the High Ganges River Floodplain and Madhupur tract of Bangladesh [5,32,33]; three times more in the active Brahmaputra-Jamuna Floodplain Chars of Bangladesh [34], but $42 \%$ more wheat equivalent yield (WEY) in India [35], as well $82 \%$ higher system REY when compared to double to four crop-based systems [36]. In other, reported that cropping system intensification from three to four crop-based system increased system REY by $38-44 \%$ across the different agroecological zones of Bangladesh [37-39], similar to our study, whereas it was lower by $26 \%$ [40] and much higher ( $81 \%)$ as reported by Islam et al. [41] compared to our study. In the recent, Saha et al. [42] reported cropping system intensification increased 211 to $360 \%$ more REY by two to four crop based cropping system in the salt-affected coastal zones of Bangladesh. The amount of increase REY varies due to the number of crops involved in the cropping system (two or three or four crop bases system) and types of crops as well as different ecosystems across the world.

Bangladesh has about 0.18 Mha of land under Potato-T. Boro-T. Aman cropping system occupies $2.11 \%$ of the total net cropped area; from which 10,652 hectares under the LBT agro-ecological zone. The exclusion of T. Boro rice from the conventional (Potato-T. Boro-T. Aman) cropping system and adding T. Aus rice in the improved cropping system will reduce the rice production by only $13,748 \mathrm{t}$ approximately which is a very negligible amount of the total rice production. On the other hand, the REY will be increased by $0.12 \mathrm{Mt}$ in the improved cropping system as compared to the conventional system which is more than 8 times higher compared to the amount of less rice production. Therefore, it can be said that because of the introduction of T. Aman-Potato-Cucumber-T. Aus cropping system, will not only decrease the rice production significantly but also increase the REY. As a result, food production in Bangladesh will be safe and sustainable. Moreover, the mean system sustainable yield index (SYI) in the improved (T. Aman-Potato-Cucumber-T. Aus) cropping system (0.91), similar to the existing cropping system (0.90), clearly indicated that the replacement of $\mathrm{T}$. Boro by the cucumber and T. Aus rice never showed any negative effect on sustainable crop production. Besides, a significant amount of groundwater saves due to the discard of T. Boro rice, which ultimately play a positive role in sustainability.

\subsection{System Protein Output}

There was a significant difference on system protein output in both the year (Table 6). In both the year system protein output was decreased (by 17-18\%) in the improved cropping system than that of the existing cropping system. The reason was mainly due to the higher yield of rice (especially the T. Boro rice) as well as the high protein content (8.8\%) compared to the cucumber (higher yield but low protein content, $0.7 \%$ ) in the improved cropping system. However, the averaged protein output over the two years was also increased by $21 \%$ in the existing cropping system. Alam et al. [5] reported that intensification of cropping system from double (T. Boro-T. Aman) to triple (Wheat-mungbean-Aman) increased total system protein output by $3 \%$, due to the introduction of high protein content (mungbean) crop; that is reverse to our current study. Cropping system intensification from wheatwheat (double) to wheat-wheat-wheat (triple) system increased the system protein output 
by $7 \%$ and from wheat-wheat-wheat (three crops) to wheat-canola-wheat-field pea (four crops) by 56\% in a long term study (2004-2015) in Saskatchewan, Canada [43]. In other Sharma et al. [44] showed that system protein output has been increased by $30-46 \%$ in ricepotato-mungbean and 19-26\% in rice-rapeseed-mungbean cropping system compared to the rice-wheat cropping system in India. The variation of system protein output among the cropping systems due to the inclusion of various crop in the crop sequence that produced various protein.

Table 6. Annual cropping system protein output $\left(\mathrm{kg} \mathrm{ha}^{-1}\right)$ during 2018-19 and 2019-20, and averaged over both years.

\begin{tabular}{ccccc}
\hline \multirow{2}{*}{ Crops/Systems } & \multicolumn{5}{c}{ Cropping System } \\
\cline { 2 - 5 } & CS1 & CS2 & $t$-Value & Level of Significance \\
\hline T. Aman & 371 & $303-19$ & 4.19 & $* *$ \\
Potato & 79 & 94 & 4.77 & $*$ \\
T. Boro & 416 & - & - & - \\
Cucumber & - & 3 & - & - \\
T. Aus & - & 318 & - & $* *$ \\
System total & 866 & 718 & 4.53 & $*$ \\
\hline T. Aman & & $2019-20$ & & $*$ \\
Potato & 363 & 295 & 3.69 & - \\
T. Boro & 82 & 96 & 4.99 & - \\
Cucumber & 401 & - & - & $*$ \\
T. Aus & - & 3 & - & $*$ \\
System total & - & 303 & - & $*$ \\
\hline Mean system total & 846 & 697 & 4.68 & $* .61$ \\
\hline
\end{tabular}

$\overline{\mathrm{CS} 1}=\mathrm{T}$. Aman-Potato-T. Boro (Existing cropping system), CS2 = T. Aman-Potato-Cucumber-T. Aus (Improved cropping system); ${ }^{* *}$, significant at $1 \%$ level of probability.

\subsection{System Energy Output (Grain, Harvested Straw)}

There was a significant difference in the energy output of potato and T. Aman crop each year, as well as the total system (Table 7). The energy output of the T. Aman-Potato-T. Boro cropping system (mean $446 \mathrm{GJ} \mathrm{ha}^{-1}$ ) over the two years was significantly higher (averaged by $9 \%$ ) compared to the T. Aman-potato-cucumber-T. Aus cropping system each year. The lower system energy output in the T. Aman-potato-cucumber-T. Aus cropping system mainly due to the low energy output of cucumber $\left(0.8 \mathrm{MJ} \mathrm{kg}^{-1}\right)$, while it was much higher for T. Boro rice (14.7 MJ kg-1 from grain and $15.6 \mathrm{MJ} \mathrm{kg}^{-1}$ from straw) in the existing T. Aman-potato-T. Boro cropping system. The intensification and diversification of cropping from the two to three crop based cropping system increased the system energy output by $15-42 \%[26,32,35,45]$; reverse to this study. In India, the system energy out was lower by $6 \%$ in rice-potato, by $2 \%$ in rice-veg. pea-wheat-green gram and by $4 \%$ in the rice-mustard-green gram cropping system compared to the ricewheat cropping system $[46,47]$. The system energy output increased by $59 \%$ from single to double, $14-38 \%$ from double to triple crop-based system and by $5 \%$ from three to four crop based cropping system in India [44,48-50]. The reason for variations among the different cropping systems mainly due to the variations of crops used (produced various energy output) in the cropping system. 
Table 7. Individual crop and annual cropping system energy output (GJ ha ${ }^{-1}$ ) during 2018-19 and 2019-20 and averaged over the two years.

\begin{tabular}{ccccc}
\hline \multirow{2}{*}{ Crops/Systems } & \multicolumn{5}{c}{ Cropping System } \\
\cline { 2 - 5 } & CS1 & CS2 & $t$-Value & Level of Significance \\
\hline T. Aman & 180 & $2018-19$ & $* *$ \\
Potato & 77 & 153 & 3.51 & $* *$ \\
T. Boro & 196 & - & 5.17 & - \\
Cucumber & - & 11 & - & - \\
T. Aus & - & 152 & - & $* *$ \\
System total & 454 & 413 & 3.17 & $* *$ \\
\hline & & & $*$ \\
\hline T. Aman & 175 & 148 & 3.03 & - \\
Potato & 79 & 99 & 6.69 & - \\
T. Boro & 185 & - & - & $*$ \\
Cucumber & - & 11 & - & $* *$ \\
T. Aus & - & 144 & - & $* 36$ \\
System total & 439 & 403 & 3.96 & \\
\hline Mean system total & 446 & 408 & & \\
\hline CS1 = T. Aman-Potato-T. Boro (Existing cropping system), CS2 = T. Aman-Potato-Cucumber-T. Aus (Improved \\
cropping system); $*$ significant at $1 \%$ level of probability.
\end{tabular}

\subsection{Crop and System Profitability}

All crops in both the cropping systems were profitable, with positive gross margin and net return, as well as BCR $>1$, regardless of the amount of labour cost in the analysis (Table 8). The gross margin of cucumber used in the improved cropping system was $18-59 \%$ higher compared to the other crops due to the high yield as well as received good price of cucumber. However, with $100 \%$ activity, the total cost of potato production was about $35-72 \%$ higher than that of the other crops, mainly due to the high seed price of potato (1200 US\$ ha ${ }^{-1}$ ) and labour costs (Tables 2 and 3). The total variable cost for all crops decreased with the decrease rate of labour cost in the analysis (Table 8).

The net result was similar gross margins (means US\$ 1032-1265 ha ${ }^{-1}$ ) for potato and cucumber crops, near about double gross margins for T. Aman (mean US $\$ 758 \mathrm{ha}^{-1}$ ) and T. Boro (mean US\$ $666 \mathrm{ha}^{-1}$ ) and lowest gross margin for T. Aus (mean US\$ $521 \mathrm{ha}^{-1}$ ). Similarly, the net return was ranked the highest for cucumber (mean US\$ 1119 ha $^{-1}$ ), slightly lower (21\%) in potato (mean US\$ $885 \mathrm{ha}^{-1}$ ) with a great extent of $49-67 \%$ for the rice crops. The net return of T. Aus and T. Boro were low at US\$ 198 and US\$ $246 \mathrm{ha}^{-1}$ when $100 \%$ of labour was costed, due to more labour required (about 80 no.) as well as high labour wedges. Mean BCR was highest for T. Aman, similar to cucumber, and least for T. Boro. Both the cropping systems were also profitable (Table 9).

The gross return for the improved (T. Aman-potato-cucumber-T. Aus) cropping system (US\$ $8065 \mathrm{ha}^{-1}$ ) was about $49 \%$ more than the existing (T. Aman-potato-T. Boro) cropping system (US\$ $5399 \mathrm{ha}^{-1}$ ), while the total cost was slightly higher (by $28 \%$ ). Gross margin ranged from US\$3078-4569 ha ${ }^{-1}$, while net return ranged from US\$ 2490-3981 ha ${ }^{-1}$ and BCR from 1.45-1.97 across the different levels of labour costed (0-100\% activity). The gross margin of the improved (T. Aman-potato-cucumber-T. Aus) cropping systems was US\$ 1426-1805 ha ${ }^{-1}$, much higher (74\%) compared to the existing (T. Aman-potato-T. Boro) cropping system, with an average net return of US\$ $1617 \mathrm{ha}^{-1}$. The intensification and diversification from three to four crop based cropping system increased gross margin by $13-29 \%$ [38,40]; even though doubled from in Mustard-Mungbean-T. AusT. Aman (1914 US\$ ha ${ }^{-1}$ ) cropping system compared to Mustard-Dibbled Aus-T. Aman (924 US\$ ha ${ }^{-1}$ ) cropping system [41]. In another, Alam et al. [5] reported that intensification from double to triple cropping system increased gross margin by $26 \%$ and net return by double due to higher returns and lower production cost in the High Ganges River 
Floodplain of Bangladesh. Recently. Mondal et al. [51] reported that cropping system intensification increased profitability by 2 to 5 folds in the coastal zone of West Bengal, India. The wide range of variations on gross margin and economic profitability due to the type of crops involved in the cropping system and also price received by the farmers with low input cost.

Table 8. Economics of the five crops grown in the cropping systems.

\begin{tabular}{|c|c|c|c|c|c|}
\hline $\begin{array}{c}\text { Economic } \\
\text { Parameter a }^{\text {a }}\end{array}$ & Potato & Cucumber & T. Aus & T. Aman & T. Boro \\
\hline \multicolumn{6}{|c|}{ A. Gross Return } \\
\hline Activity $0-100 \%$ & $3132 \pm 39$ & $2502 \pm 58$ & $1052 \pm 19$ & $1133 \pm 16$ & $1382 \pm 31$ \\
\hline \multicolumn{6}{|c|}{ B. Total Variable Cost } \\
\hline Activity $100 \%$ & 2316 & 1448 & 707 & 516 & 915 \\
\hline Activity 75\% & 2208 & 1342 & 619 & 446 & 816 \\
\hline Activity 50\% & 2100 & 1236 & 531 & 375 & 716 \\
\hline Activity $25 \%$ & 1992 & 1130 & 442 & 305 & 617 \\
\hline Activity $0 \%$ & 1884 & 1024 & 354 & 234 & 517 \\
\hline \multicolumn{6}{|c|}{ C. Total Fixed Cost } \\
\hline Activity $100 \%$ & 147 & 147 & 147 & 184 & 221 \\
\hline Activity 75\% & 147 & 147 & 147 & 184 & 221 \\
\hline Activity $50 \%$ & 147 & 147 & 147 & 184 & 221 \\
\hline Activity $25 \%$ & 147 & 147 & 147 & 184 & 221 \\
\hline Activity $0 \%$ & 147 & 147 & 147 & 184 & 221 \\
\hline \multicolumn{6}{|c|}{ D. Total Cost $(B+C)$} \\
\hline Activity $100 \%$ & 2463 & 1595 & 854 & 700 & 1136 \\
\hline Activity 75\% & 2355 & 1489 & 766 & 630 & 1037 \\
\hline Activity $50 \%$ & 2247 & 1383 & 678 & 559 & 937 \\
\hline Activity $25 \%$ & 2139 & 1277 & 589 & 489 & 838 \\
\hline Activity $0 \%$ & 2031 & 1171 & 501 & 418 & 738 \\
\hline \multicolumn{6}{|c|}{ E. Gross Margin $(\mathrm{A}-\mathrm{B})$} \\
\hline Activity $100 \%$ & $816 \pm 39$ & $1054 \pm 58$ & $345 \pm 19$ & $617 \pm 16$ & $467 \pm 31$ \\
\hline Activity 75\% & $924 \pm 39$ & $1160 \pm 58$ & $433 \pm 19$ & $687 \pm 16$ & $566 \pm 31$ \\
\hline Activity $50 \%$ & $1032 \pm 39$ & $1266 \pm 58$ & $521 \pm 19$ & $758 \pm 16$ & $666 \pm 31$ \\
\hline Activity $25 \%$ & $1140 \pm 39$ & $1372 \pm 58$ & $609 \pm 19$ & $828 \pm 16$ & $765 \pm 31$ \\
\hline Activity $0 \%$ & $1248 \pm 39$ & $1478 \pm 58$ & $698 \pm 19$ & $899 \pm 16$ & $865 \pm 31$ \\
\hline \multicolumn{6}{|c|}{ F. Net Return $(A-D)$} \\
\hline Activity $100 \%$ & $669 \pm 39$ & $907 \pm 58$ & $198 \pm 19$ & $433 \pm 16$ & $246 \pm 31$ \\
\hline Activity 75\% & $777 \pm 39$ & $1013 \pm 58$ & $286 \pm 19$ & $503 \pm 16$ & $345 \pm 31$ \\
\hline Activity $50 \%$ & $885 \pm 39$ & $1119 \pm 58$ & $374 \pm 19$ & $574 \pm 16$ & $445 \pm 31$ \\
\hline Activity $25 \%$ & $993 \pm 39$ & $1225 \pm 58$ & $462 \pm 19$ & $644 \pm 16$ & $544 \pm 31$ \\
\hline Activity $0 \%$ & $1101 \pm 39$ & $1331 \pm 58$ & $551 \pm 19$ & $715 \pm 16$ & $644 \pm 31$ \\
\hline \multicolumn{6}{|c|}{ G. BCR (Undiscounted)(A/D) } \\
\hline Activity $100 \%$ & $1.27 \pm 0.02$ & $1.57 \pm 0.04$ & $1.23 \pm 0.02$ & $1.62 \pm 0.02$ & $1.22 \pm 0.03$ \\
\hline Activity 75\% & $1.33 \pm 0.02$ & $1.68 \pm 0.04$ & $1.37 \pm 0.02$ & $1.80 \pm 0.03$ & $1.33 \pm 0.03$ \\
\hline Activity 50\% & $1.39 \pm 0.02$ & $1.81 \pm 0.04$ & $1.55 \pm 0.03$ & $2.03 \pm 0.03$ & $1.47 \pm 0.03$ \\
\hline Activity $25 \%$ & $1.46 \pm 0.02$ & $1.96 \pm 0.05$ & $1.78 \pm 0.03$ & $2.32 \pm 0.03$ & $1.65 \pm 0.04$ \\
\hline Activity 0\% & $1.54 \pm 0.02$ & $2.14 \pm 0.05$ & $2.10 \pm 0.04$ & $2.71 \pm 0.04$ & $1.87 \pm 0.04$ \\
\hline
\end{tabular}


Table 9. Economics of treatments under the two cropping systems evaluated in the field experiment.

\begin{tabular}{|c|c|c|}
\hline \multirow{2}{*}{ Economics } & \multicolumn{2}{|c|}{ Mean } \\
\hline & CS1 & CS2 \\
\hline \multicolumn{3}{|c|}{ A. Gross Return } \\
\hline Activity $0-100 \%$ & $5399 \pm 69$ & $8065 \pm 131$ \\
\hline \multicolumn{3}{|c|}{ B. Total Variable Cost } \\
\hline Activity $100 \%$ & 3747 & 4987 \\
\hline Activity 75\% & 3470 & 4615 \\
\hline Activity $50 \%$ & 3191 & 4242 \\
\hline Activity $25 \%$ & 2914 & 3869 \\
\hline Activity $0 \%$ & 2635 & 3496 \\
\hline \multicolumn{3}{|c|}{ C. Total Fixed Cost } \\
\hline Activity $100 \%$ & 589 & 588 \\
\hline Activity $75 \%$ & 589 & 588 \\
\hline Activity 50\% & 589 & 588 \\
\hline Activity $25 \%$ & 589 & 588 \\
\hline Activity $0 \%$ & 589 & 588 \\
\hline \multicolumn{3}{|c|}{ D. Total Cost $(B+C)$} \\
\hline Activity $100 \%$ & 4336 & 5575 \\
\hline Activity $75 \%$ & 4059 & 5203 \\
\hline Activity 50\% & 3780 & 4830 \\
\hline Activity $25 \%$ & 3503 & 4457 \\
\hline Activity $0 \%$ & 3224 & 4084 \\
\hline \multicolumn{3}{|c|}{ E. Gross Margin $(A-B)$} \\
\hline Activity $100 \%$ & $1652 \pm 69$ & $3078 \pm 131$ \\
\hline Activity 75\% & $1929 \pm 69$ & $3450 \pm 131$ \\
\hline Activity 50\% & $2208 \pm 69$ & $3823 \pm 131$ \\
\hline Activity $25 \%$ & $2485 \pm 69$ & $4196 \pm 131$ \\
\hline Activity $0 \%$ & $2764 \pm 69$ & $4569 \pm 131$ \\
\hline \multicolumn{3}{|c|}{ F. Net Return $(A-D)$} \\
\hline Activity $100 \%$ & $1063 \pm 69$ & $2490 \pm 131$ \\
\hline Activity 75\% & $1340 \pm 69$ & $2862 \pm 131$ \\
\hline Activity $50 \%$ & $1619 \pm 69$ & $3235 \pm 131$ \\
\hline Activity 25\% & $1896 \pm 69$ & $3608 \pm 131$ \\
\hline Activity $0 \%$ & $2175 \pm 69$ & $3981 \pm 131$ \\
\hline \multicolumn{3}{|c|}{ G. BCR (Undiscounted)(A/D) } \\
\hline Activity $100 \%$ & $1.25 \pm 0.02$ & $1.45 \pm 0.02$ \\
\hline Activity $75 \%$ & $1.33 \pm 0.02$ & $1.55 \pm 0.03$ \\
\hline Activity 50\% & $1.43 \pm 0.02$ & $1.67 \pm 0.03$ \\
\hline Activity $25 \%$ & $1.54 \pm 0.02$ & $1.81 \pm 0.03$ \\
\hline Activity $0 \%$ & $1.67 \pm 0.02$ & $1.97 \pm 0.03$ \\
\hline
\end{tabular}

CS1 = T. Aman-Potato-T. Boro (Existing cropping system), CS2 = T. Aman-Potato-Cucumber-T. Aus (Improved cropping system). Data are mean \pm standard error in US\$ (I US\$ $=84.58$ BDT).

\section{Conclusions}

From the results and discussion of the present study, it can be concluded that crop diversification in the existing T. Boro-based cropping system of Level Barind Tract of Bangladesh with the introduction of the high yielding potato, cucumber, and T. Aus rice, improved the system productivity, profitability and sustainability in terms of higher gross margin (by $74 \%$ ), net return (double) and benefit-cost ratio (BCR) (1.69 vs. 1.44). The improved cropping system increased the gross return by $2666 \mathrm{USS} \mathrm{ha}^{-1}(49 \%)$ and net return by 1616 US $\$$ ha $^{-1}$ (double) as well as higher BCR (1.69) as compared to the existing system as a result of the higher prices for potato, cucumber and two rice crops 
in the improved cropping system than the existing system. Although the productivity and profitability of the improved cropping system were found the maximum, while the output of protein and energy were found lower (by 17\% and $9 \%$, respectively); it is the result of the less content of protein and energy value in cucumber. However, the improved cropping system did not show any significant difference on SYI (0.91 vs. 0.90), indicated that this is a sustainable cropping system. Therefore, the implementation of the improved four crops-based cropping system may be recommended for the well-drained Level Barind Tract of Bangladesh, which lead to ensure the sustainable food production of the increasing population and also reduce the adverse effect on the environment.

Author Contributions: Conceptualization, M.J.A., A.A.-M., M.A.I., M.F.H., M.A.A. and A.H.; methodology, M.J.A. and A.A.-M.; software, M.A.A. and M.J.A.; validation, M.A.A. and M.J.A.; formal analysis, M.A.A., M.J.A. and A.H.; investigation, A.A.-M. and M.J.A.; resources, A.A.-M., M.F.H., M.A.A.; data curation, A.A.-M., M.J.A. and A.H.; writing—original draft preparation, M.J.A., A.A.-M., M.A.I., M.F.H., M.A.A. and A.H.; writing-review and editing E.S.D., E.I.E.-H., M.M.H., N.B. and A.H.; visualization, A.A.-M. and M.J.A.; supervision, A.A.-M., M.F.H. and M.A.A.; project administration A.A.-M., M.A.A. and M.M.H.; funding acquisition, E.S.D., E.I.E.-H., M.M.H., N.B. and A.H. All authors have read and agreed to publish the current version of the manuscript in Sustainability.

Funding: The current work was funded by the Director-General of Bangladesh Agricultural Research Institute (BARI), Joydebpur, Gazipur and Taif University Researchers Supporting Project number (TURSP 2020/85), Taif University, Taif, Saudi Arabia.

Institutional Review Board Statement: Not applicable.

Informed Consent Statement: Not applicable.

Data Availability Statement: Data recorded in the current study are available in all Tables and Figures of the manuscript.

Acknowledgments: We earnestly thank the Director-General of Bangladesh Agricultural Research Institute (BARI), Joydebpur, Gazipur for awarding research expenses and delivering the services for this study. The authors also extend their appreciation to Taif University for funding current work by Taif University Researchers Supporting Project number (TURSP 2020/85), Taif University, Taif, Saudi Arabia.

Conflicts of Interest: The authors declare no conflict of interest.

\section{References}

1. BBS. Bangladesh Bureau of Statistics, Dhaka, Bangladesh. 2019. Available online: www.bbs.gov.bd (accessed on 18 March 2021).

2. BBS. Bangladesh Bureau of Statistics, Dhaka, Bangladesh. 2016. Available online: www.bbs.gov.bd.2016 (accessed on 18 March 2021).

3. FAOSTAT. 2019. Available online: http://www.fao.org/faostat/en/\#data/QC (accessed on 18 March 2021).

4. Ganesh-Kumar, A.; Prasad, S.K.; Pullabhotla, H. Supply and Demand for Cereals in Bangladesh: 2010-2030; IFPRI Discussion Paper 1186; International Food Policy Research Institute (IFPRI): Washington, DC, USA, 2012; pp. 1-36. Available online: http:/ / ebrary.ifpri.org/cdm/ref/collection/p15738coll2/id/126957 (accessed on 9 May 2021).

5. Alam, M.J.; Humphreys, E.; Sarkar, M.A.R.; Sudhir, Y. Intensification and diversification increase land and water productivity and profitability of rice-based cropping systems on the High Ganges River Floodplain of Bangladesh. Field Crops Res. 2017, 209, 10-26. [CrossRef]

6. BRRI. Annual Report for 1994; Bangladesh Rice Research Institute: Gazipur, Bangladesh, 1998; p. 260.

7. Ladha, J.K.; Pathak, H.; Gupta, R.K. Sustainability of the rice-wheat cropping system: Issues, constraints and remedial options. J. Crop Improv. 2007, 19, 125-136. [CrossRef]

8. Khan, M.S.A.; Aziz, M.A. Impact of sowing date induced temperature and management practices on development and yield of mustard. Bangladesh Agron. J. 2015, 18, 45-52. [CrossRef]

9. Planning Commission. Steps towards Change-National Strategy for Accelerated Poverty Reduction II (Revised); FY 2009-11; Government of the People's Republic of Bangladesh: Dhaka, Bangladesh, 2009; pp. 1-272.

10. Nasim, M.; Shahidullah, S.A.; Saha, A.; Muttaleb, M.A.; Aditya, T.L.; Ali, M.A.; Kabir, M.S. Distribution of Crops and Cropping Patterns in Bangladesh. Bangladesh Rice J. 2017, 21, 1-55. [CrossRef] 
11. Ladha, J.K.; Kumar, V.; Alam, M.M.; Sharma, S.; Gathala, M.; Chandna, P.; Saharawat, Y.S.; Balasubramanian, V. Integrating crop and resource management technologies for enhanced productivity, profitability, and sustainability of the rice-wheat system in South Asia. In Integrated Crop and Resource Management in the Rice-Wheat System of South Asia; Ladha, J.K., Singh, Y., Erenstein, O., Hardy, B., Eds.; International Rice Research Institute: Los Baños, Philippines, 2009; pp. 69-108.

12. Alam, M.J.; Humphreys, E.; Sarkar, M.A.R.; Sudhir, Y. Comparison of dry seeded and puddled transplanted rainy season rice on the High Ganges River Floodplain of Bangladesh. European J. Agron. 2018, 96, 120-130. [CrossRef]

13. Shamsudduha, M.; Chandler, R.E.; Taylor, R.G.; Ahmed, K.M. Recent trends in groundwater levels in a highly seasonal hydrological system: The GangesBrahmaputra-Meghna delta. Hydrol. Earth Syst. Sci. 2009, 13, 2373-2385. [CrossRef]

14. Christopher, O.A.; Haque, A.M.M. Arsenic contamination in irrigation water for rice production in Bangladesh: A review. Trends Appl. Sci. Res. 2012, 7, 331-349.

15. DPHE (Department of Public Health Engineering). Groundwater Studies for Arsenic Contamination in Bangladesh. Rapid Investigation Phase. Final Report. Mott MacDonald International Ltd. and British Geological Survey; Report prepared for Department of Public Health Engineering (Bangladesh) and Department for International Development, UK; The Department of Public Health Engineering (DPHE): Dhaka, Bangladesh, 2000.

16. Harrington, L.W.; Fujisaka, S.; Morris, M.L.; Hobbs, P.R.; Sharma, H.C.; Singh, R.P.; Chaudhury, M.K.; Dhiman, S.D. Wheat and rice in Karnal and Kurukshetra Districts, Haryana, India: Farmer's Practice, Problems and an Agenda for Action; Haryana Agricultural University; Indian Council for Agricultural Research; CIMMYT (International Maize and Wheat Improvement Center) and IRRI (International Rice Research Institute): Delhi, India, 1993; pp. 1-44.

17. BADC. Bangladesh Agricultural Development Corporation, Survey Report on Irrigation Equipment and Irrigated Area in Boro/2003 Season; Ministry of Agriculture, Government of the People's Republic of Bangladesh: Dhaka, Bangladesh, 2004; p. 200.

18. Tuong, T.P.; Bouman, B.A.M. Rice production in water scarce environments. In Water Productivity in Agriculture: Limits and Opportunities for Improvement; Kijne, J.W., Barker, R., Molden, D., Eds.; CABI Publishing: Wallingford, UK, 2003 ; pp. 53-67.

19. FAO (Food and Agriculture Organization). Arsenic Threat in Rice: Reducing Arsenic Levels in Rice through Improved Irrigation Practices. 2007. Available online: http:/ / www.fao.org/newsroom/en/news/2007/1000734/index.html (accessed on 9 May 2021).

20. Rahman, M.A.; Hasegawa, H.; Rahman, M.M.; Miah, M.A.M.; Tasmin, A. Arsenic accumulation in rice (Oryza sativa L.): Human exposure through food chain. Ecotoxicol. Environ. Saf. 2008, 69, 317-324. [CrossRef]

21. Panaullah, G.M.; Alam, T.; Hossain, M.B.; Leoppert, R.H.; Lauren, J.G.; Meisner, C.A.; Ahmed, Z.U.; Duxbury, J.M. Arsenic toxicity to rice (Oryza sativa L.) in Bangladesh. Plant Soil. 2009, 317, 31-39. [CrossRef]

22. BARC. 2018. Available online: http://www.barc.gov.bd/site/page/8b1d53d5-3b6d-4758-a3de-cb34b0f95537/FertlizerRecommendationGuide2018 (accessed on 18 March 2021).

23. Biswas, B.; Ghosh, D.C.; Dasgupta, M.K.; Trivedi, N.; Timsina, J.; Dobermann, A. Integrated assessment of cropping systems in the Eastern Indo-Gangetic plain. Field Crops Res. 2006, 99, 35-47. [CrossRef]

24. Timsina, J.; Quayyum, M.A.; Connor, D.J.; Saleque, M.; Haq, F.; Panaullah, G.M.; Jahan, M.A.H.S.; Begum, R.A. Effect of fertilizer and mungbean residue management on total productivity, soil fertility and N-use efficiency of intensified rice-wheat systems. Int. J. Agric. Res. 2006, 1, 41-52.

25. Annon. Nutrition Value. 2021. Available online: https://www.nutritionvalue.org (accessed on 18 March 2021).

26. Khan, M.A.; Hossain, S.M.A. Study on energy input, output and energy use efficiency of major jute based cropping pattern. Bangladesh J. Sci. Indus. Res. 2007, 42, 195-202. [CrossRef]

27. Canakci, M.; Akinci, I. Energy use pattern analyses of greenhouse vegetable production. Energy 2006, 31, 1243-1256. [CrossRef]

28. Samant, T.K. System productivity, profitability, sustainability and soil health as influenced by rice based cropping systems under mid central table land zone of Odisha. Int. J. Agric. Sci. 2015, 7, 746-749.

29. Singh, D.; Bhaskar, B.P.; Baruah, U.; Sarkar, D. Diversification of Rice (Oryza sativa L.) Based Cropping Systems for Higher Productivity and Resource-use Efficiency in Major Soil Series of Upper Brahmaputra Valley of Assam. Indian J. Dryland Agric. Res. Dev. 2013, 28, 26-32.

30. Jat, R.A.; Dungrani, R.A.; Arvadia, M.K.; Sahrawat, K.L. Diversification of rice (Oryza sativa L.)-based cropping systems for higher productivity, resource-use efficiency and economic returns in south Gujarat, India. Arch. Agron. Soil Sci. 2012, 58, 561-572. [CrossRef]

31. Nagoli, S.B.; Basavanneppa, M.A.; Sawargaonkar, G.L.; Biradar, D.P.; Biradar, S.A.; Tevari, P. Diversification of Rice-rice (Oryza sativa L.) cropping systems for productivity, profitability and resource use efficiency in Tunga Bhadra Project Command Area. BEPLS 2017, 6, 108-114.

32. Alam, M.J.; Ahmed, S.; Islam, M.K.; Islam, R.; Islam, M. Effect of cropping system and rice residue retention on crop productivity and soil physical properties in rice-based cropping system of Bangladesh. Agriculturists 2019, 17, 14-30. [CrossRef]

33. Khan, M.A.H.; Sultana, N.; Akter, N.; Zaman, M.S.; Choudhury, A.K. Increasing Cropping intensity and productivity through mungbean inclusion in wheat-fallow-T. Aman rice cropping pattern. Bangladesh J. Agric. Res. 2018, 43, 333-343. [CrossRef]

34. Mahmud, A.A.; Alam, M.J.; Islam, M.A.; Molla, M.S.H.; Ali, M.A. Millet-Jute-T. Aman Cropping Pattern for Increasing System Productivity in the Active Brahmaputra-Jamuna Floodplain Chars. Agriculturists 2020, 18, 129-136. [CrossRef]

35. Chauhan, D.S.; Sharma, R.K.; Kharub, A.S.; Tripathi, S.C.; Chhokar, R.S. Effect of crop intensification on productivity, profitability, energetics and soil fertility in rice (Oryza sativa)-wheat (Triticum aestivum) cropping system in north-western platins. Indian J. Agric. Sci. 2001, 71, 299-302. 
36. Hossain, I.; Mondal, M.R.I.; Islam, M.J.; Aziz, M.A.; Khan, A.S.M.M.R.; Begum, F. Four crops based cropping pattern studies for increasing cropping intensity and productivity in Rajshahi region of Bangladesh. Bangladesh Agron. J. 2014, 17, 55-60. [CrossRef]

37. Islam, M.A.; Islam, M.J.; Ali, M.A.; Khan, A.S.M.M.R.; Hossain, M.F.; Moniruzzaman, M. Transforming Triple Cropping System to Four Crops Pattern: An Approach of Enhancing System Productivity through Intensifying Land Use System in Bangladesh. International J. Agron. 2018, 2018, 7149835. [CrossRef]

38. Rahman, M.S.; Islam, M.T.; Prodhan, M.Z.H.; Hasan, M.K.; Khan, A.S.M.M.R. Productivity and profitability of improved versus existing cropping pattern in Kushtia region. Bangladesh J. Agric. Res. 2018, 43, 587-598. [CrossRef]

39. Sarker, M.A.Z.; Alam, M.A.; Hossain, A.; Mannaf, M.A. Agro-Economic Performance of Crop Diversification in Rice Based Cropping Systems of Northwest Bangladesh. Agric. Forest. Fish. 2014, 3, 264-270. [CrossRef]

40. Hossain, M.H.; Bhowal, S.K.; Bashir, M.M.; Khan, A.S.M.M.R. Productivity and Profitability of Four Crops Based Cropping Pattern in Cumilla Region of Bangladesh. Agriculturists 2018, 16, 88-92. [CrossRef]

41. Islam, M.S.; Hossain, A.; Timsina, J.; Saif, H.; Sarker, M.M.R.; Khan, A.S.M.M.R.; Hasan, M.K.; Zahan, T.; Sabagh, A.E.L.; Akdeniz, H.; et al. Feasibility and Financial Viability Study of an Intensive Mustard -Mungbean-Transplanted Aus Rice-Transplanted Aman Rice Cropping System in a Non-Saline Coastal Ecosystem of Bangladesh. Philippine Agric. Sci. 2020, $103,73-83$.

42. Saha, R.R.; Rahman, M.A.; Rahman, M.H.; Mainuddin, M.; Bell, R.; Gaydon, D.S. Cropping System Intensification for Increasing Crop Productivity in Salt-Affected Coastal Zones of Bangladesh. Proceedings 2019, 36, 172. [CrossRef]

43. St. Luice, M.; Lemke, R.; Gan, Y.; McConkey, B.; May, W.; Campbell, C.; Zentner, R.; Wang, H.; Kroebel, R.; Fernandez, M.; et al. Diversifying cropping systems enhances productivity, stability and nitrogen use efficiency. Agron. J. 2020, 112, 1517-1536. [CrossRef]

44. Sharma, S.N.; Prasad, R.; Dwivedi, M.K.; Kumar, S.; Davari, M.R.; Ram, M. Effect of cropping system on production and chemical and biological properties of soil. Arch. Agron. Soil Sci. 2009, 55, 429-438. [CrossRef]

45. Walia, S.S.; Gill, R.S.; Aulakh, C.S.; Kaur, M. Energy-efficiency indices of alternative cropping systems of North-West India. Indian J. Agron. 2014, 59, 359-363.

46. Soni, P.; Sinha, R.; Perret, S.R. Energy use and efficiency in selected rice-based cropping systems of the Middle-Indo Gangetic Plains in India. Energy Rep. 2018, 4, 554-564. [CrossRef]

47. Shilpha, S.M.; Soumya, T.M.; Mamathashree, C.M.; Girijesh, G.K. Energetics in Various Cropping Systems. Int. J. Pure App. Biosci. 2018, 6, 303-323.

48. Mandal, K.G.; Saha, K.P.; Hati, K.M.; Singh, V.V.; Misra, A.K.; Ghosh, P.K.; Bandyopadhyay, K.K. Cropping Systems of Central India: An Energy and Economic Analysis. J. Sust. Agri. 2005, 25, 117-140. [CrossRef]

49. Prajapat, K.; Vyas, A.K.; Dhar, S.; Jain, N.K.; Hashim, M.; Choudhary, G.L. Energy input-output relationship of soybean-based cropping systems under different nutrient supply options. J. Environ. Biol. 2018, 39, 93-101. [CrossRef]

50. Chaudhary, V.P.; Gangwar, B.; Pandey, D.K. Auditing of Energy Use and Output of Different Cropping Systems in India. Agric. Eng. Int. CIGR-e J. 2006, 8, 1-13.

51. Mandal, S.; Maji, B.; Sarangi, S.K.; Mahanta, K.K.; Mandal, U.K.; Burman, D.; Digar, S.; Mainuddin, M.; Sharma, P.C. Economics of cropping system intensification for small-holder farmers in coastal salt-affected areas in West Bengal: Options, challenges and determinants. Decision 2020, 47, 19-33. [CrossRef] 